\title{
MASYARAKAT ISLAM DI KAMPUNG KEPAON KOTA DENPASAR PROVINSI BALI
}

\author{
Islamic Society In The Kepaon Village \\ Denpasar City Bali Province
}

\author{
Nuryahman \\ Balai Pelestarian Nilai Budaya Bali, NTB, NTT \\ Jl. Raya Dalung - Abianbase No. 107, Badung, Denpasar Bali \\ Telp. (0361) 439547, Fax. (0361) 439546 \\ Email:nuryahman80@yahoo.com
}

Naskah diterima tanggal 09 Maret 2015. Naskah direvisi tanggal 01 April 2015. Naskah disetujui tanggal 04 November 2015.

\begin{abstract}
Abstrak
Kampung Kepaon merupakan salah satu pemukiman masyarakat Islam yang berada di tengah kota Denpasar, dimana sebagian besar atau mayoritas beragama Hindu. Dari segi sejarah kampung Kepaon berkembang sejak tahun 1891 dan erat kaitannya dengan keberadaan kerajaan Badung. Kehidupan masyarakat dan tradisi budayanya sangat unik dan menarik untuk dikaji, karena menggambarkan harmoni serta keselarasan yang dibangun sejak awal kampung Kepaon ada. Di Kampung Kepaon terjadi akulturasi yang dibangun secara genealogis dan kultural yang menjadikan hubungan harmonis antara masyarakat Islam dengan masyarakat Hindu Bali disekelilingnya. Masyarakat Islam di Kampung Kepaon mempunyai identitas yang khas, sebagai hasil dari akulturasi budaya yang dimanifestasikan dalam kehidupan sehari-hari. Dengan berbagai gambaran kehidupan masyarakat Islam di Kampung Kepaon yang penuh toleransi dan harmoni dapat diambil manfaat untuk hidup penuh kedamaian, persatuan dan kesatuan secara lebih luas.
\end{abstract}

Kata kunci: masyarakat Islam, Kampung Kepaon, akulturasi, toleransi.

\begin{abstract}
Kepaon village is one of the Islamic communities settlement in the middle city of Denpasar, where most people are Hindu followers. In terms of the history, Kepaon village had developed since 1891 and it was closely related to the presence of the Badung kingdom. The community life and cultural traditions were very unique and interesting to investigate because the harmony and alignment were built since Kepaon village existed. The acculturation constructed genealogically and culturally have made harmonious relations between the Islamic community and Balinese Hindu community. The Islamic people have distinct identity, as a result of acculturation manifested in everyday life. The wide picture of life of Islamic society in Kepaon village which is full of tolerance and harmony can become the good example to live with peace and unity in broad context.
\end{abstract}

Keywords: Islamic society, Kepaon Village, Acculturation, Tolerance.

\section{PENDAHULUAN}

$\mathrm{P}$ ulau Bali atau pulau Dewata merupakan satu kesatuan nama, mulai dari nama pulaunya, pemerintahan atau provinsi, orang atau penduduknya, budaya, dan bahasanya disebut Bali.
Secara historis merupakan pusat pemerintahan Sunda Kecil pada masa awal pemerintahan Republik Indonesia yang meliputi wilayah Nusa Tenggara Barat, dan Nusa Tenggara Timur dengan ibukotanya di Singaraja.

Sebagai daerah destinasi pariwisata utama Indonesia, pesona alam dan budaya masyarakatnya 
sangat mendukung hal tersebut. Masyarakat Bali yang mayoritas beragama Hindu sangat memegang teguh adat, budaya, dan budayanya. Keunikan budaya dan keindahan alam Bali merupakan potensi yang sangat penting dalam pengembangan pariwisata. Budaya dan keindahan alam telah menjadi image pariwisata daerah Bali.

Jenis pariwisata yang dikembangkan oleh pemerintah daerah Bali adalah pariwisata budaya yang dijiwai oleh agama Hindu. Hal tersebut tertuang dalam Peraturan Daerah Nomor 3 tahun 1974, yang diperbaharui melalui Perda Nomor 3 tahun 1991. Pada Perda tersebut Bab 1, pasal 1 disebutkan antara lain Pariwisata Budaya adalah jenis kepariwisataan yang dalam perkembangan dan pengembangannya menggunakan kebudayaan Bali yang dijiwai oleh agama Hindu yang merupakan bagian dari kebudayaan Nasional sebagai potensi dasar yang dominan, yang di dalamnya tersirat satu cita-cita akan adanya hubungan timbal balik antara pariwisata dan kebudayaan sehingga keduanya meningkat secara serasi, selaras dan seimbang (I Wayan Ardika, 2007:75-76). Pariwisata budaya Bali telah diperkenalkan dan dipromosikan ke mancanegara sejak tahun 1920-an, yaitu sebuah perusahaan pelayaran Belanda KPM (Koninlijk Paketvaart Maatschapij) yang sangat berperan (I Gde Pitana, 2000: 6-7).

Sikap dan budaya keterbukaan orang Bali menjadi salah satu keberhasilan pariwisata tersebut. Masyarakat Bali sangat menerima kehadiran budaya dari manapun, dan hal itu telah terjadi sejak lama. Mereka dapat menerima, mencegah, dan meniadakan pengaruh-pengaruh negatif yang dapat ditimbulkan oleh pariwisata konsep budaya siaga melalui wacana ajeg Bali (Henk Schulte Nordhotl, 2010 : xxii-xxiii). Dengan budaya dan sikap terbuka tersebut kedatangan atau masuknya agama Islam juga sangat diterima secara terbuka sejak abad ke-18 yang lalu, sehingga terbentuklah kampung-kampung Islam di hampir setiap wilayah di Bali ada kampung Islam atau pemukiman orang Islam salah satunya adalah Kampung Islam Kepaon yang mencerminkan pemukiman Islam perkotaaan, sedangkan yang mencerminkan pemukiman Islam pedesaan yaitu Desa Islam Pegayaman di Kabupaten Buleleng Bali utara.

Keunikan kampung Islam Kepaon adalah sebagai pemukiman Islam di tengah-tengah penduduk Bali yang beragama Hindu. Dari latar belakang sejarah, perkembangan serta dinamika masyarakatnya dalam berinteraksi dengan penduduk
Bali yang beragama Hindu memang sangat menarik untuk dikaji. Dengan demikian permasalahan yang dapat ditarik antara lain, bagaimana latar belakang sejarah kampung Islam Kepaon serta perkembangannya, baik dari dinamika budaya, pendidikan dan yang utama adalah masyarakatnya.

Tujuan dari kajian ini adalah mengungkapkan keberadaan masyarakat Islam di kampung Kepaon, serta mengungkapkan bagaimana dinamika, mobilitas sosial, tranformasi sosial-ekonomi, interaksisosial yang terjadi. Persoalan-persoalan yang terkandung dalam kajian tersebut di dalamnya mengacu kepada hal-hal yang berkaitan dengan sebab-musabab dan faktor kondisional yang ada dan berkembang atau apa yang mendasari dinamika tersebut.

Di samping itu, penelitian ini juga bertujuan untuk mengumpulkan data dan informasi budaya dan kesejarahan, dalam rangka peningkatan pengetahuan dan pemahaman tentang suatu perkembangan masyarakat di sebuah kampung di kota Denpasar Bali yang mempunyai makna penting dan berguna di dalam membangun kekinian dan hari esok. Memberikan wawasan kepada generasi muda mengenai sejarah, multikultur, toleransi, semangat kebangsaan, rasa persatuan dan kesatuan.

\section{METODE PENELITIAN}

Metode yang digunakan dalam penulisan adalah metode sejarah yang terdiri dari empat langkah yaitu: heuristik atau pengumpulan data dan sumber, kritik terhadap sumber dan data (kritik intern maupun ekstern), interprestasi (pengolahan dan analisis data), dan terakhir adalah historiografi atau penulisan (Louis Gottschalk, 1986: 34). Wawancara juga dilakukan untuk memperoleh data, dengan memakai teknik wawancara bebas tidak berstruktur (Koentjaraningrat, 1997: 139).

Selain sumber dokumen penelitian ini juga menggunakan kajian pustaka. Mengenai Masyarakat Islam di Kampung Kepaon dari segi sejarah telah disinggung dari berbagai buku seperti: The Spell of Power Politik Bali 1650 -1940 Tulisan Henk Schulte Nordhot yaitu mobilisasi penggunaaan laskar Islam dari kampung Kepaon dan orang Bugis di pulau Serangan oleh kerajaan Badung untuk menyerbu kerajaan Mengwi. Mengenai masyarakat Islam Kampung Kepaon juga telah disinggung dalam buku yang ditulis Tim Peneliti Sejarah Masuknya Islam Bali, 1979/1980. Sejarah Masuknya Islam di Bali. Denpasar: Proyek Penelitian Pemda Tingkat I Propinsi Bali. 
Buku tersebut di atas sebagai bahan acuan dasar dalam penulisan ini maupun sebagai pedoman dalam melakukan wawancara. Selain itu juga dilakukan kajian pustaka dari buku teks lain, artikel-artikel, makalah, surat kabar, majalah dan informasi lain yang berhubungan dengan penulisan ini.

\section{PEMBAHASAN}

\section{Masyarakat Islam Di Kampung Kepaon, Denpasar Bali}

\section{Sejarah Kampung Islam Kepaon}

Membahas sejarah kampung Islam Kepaon sangat terkait dengan sejarah masuknya Islam di Bali. Sentuhan pertama Islam di Bali sekitar tahuntahun keruntuhan kerajaan Majapahit, maka mula pertama tempat dan asal kelompok-kelompok masyarakat Islam di Bali dapat ditelusuri secara kronologis sampai dengan pemerintahan rajaraja (kerajaan) yang ada di Bali dan datangnya kolonialisme Belanda di Bali. Jalur masuknya Islam di Bali bervariasi, melalui jalur perniagaan, jalur perkawinan, jalur politik atau atas dasar persekutuan dalam peperangan.

Islam masuk pertama kali di Bali yaitu di desa Gelgel wilayah kerajaan Klungkung pada masa pemerintahan Dalem Waturenggong, sekitar tahun 1460 Masehi. Ditandai dengan datangnya utusan dari Kesultanan Demak. Sumber yang dipergunakan diantaranya Babad Dalem dan Kidung Pemancangah, cerita lisan dan beberapa informan masyarakat di kawasan kampung-kampung Islam (Shaleh Saidi, 2007: 136). Setelah daerah Gelgel menyusul masuknya Islam di beberapa daerah di Bali. Di Jembrana dibawa oleh Syarif Abdullah bin Yahya Al-Qadry pada tahun 1800, dan bermukim di desa Loloan, yang sekarang menjadi kampung muslim Loloan. Di Buleleng di Pegayaman dan kampung Bugis Singaraja, sedangkan di Badung di Pulau Serangan.

Tentang munculnya kampung Islam Kepaon banyak sumber yang menuliskan bahwa masuknya Islam di Kepaon melalui jalur pemerintahan atau kekuasaan. Pada waktu Cokorda Pemecutan III berkuasa terdamparlah sebuah kapal di tepi pantai dekat kawasan Kuta. Mereka mengalami kerusakan perahu, mereka kemudian dimanfaatkan oleh oleh penguasa Badung Cokorda Pemecutan III. Orang-orang pendatang ini dipimpin oleh Raden Sastroningrat, seorang bangsawanMadura. Versi lain bernama Raden Suryodiningrat seorang bangsawan Madura yang tinggal Mataram (Yogyakarta). Oleh raja Badung mereka dijanjikan suatu kebebasan dan akan dikawinkan dengan putrinya apabila bersedia membantu raja dalam pertempuran melawan kerajaan Mengwi sekaligus mengalahkannya (Tim Peneliti Sejarah Masuknya Islam Bali, 1979/1980: 26).

Raden Sastroningrat menyanggupinya, kemudian bersama dengan pasukan Badung yang didukung oleh laskar Bugis dari pulau Serangan menyerbu kerajaan Mengwi. Dalam pertempuran tersebut kerajaan Mengwi berhasil dikalahkan oleh gabungan pasukan tersebut. Pasukan gabungan tersebut digambarkan sangat garang dan beringas. Orang-orang Bugis, Madura, dan Jawa di Badung dimobilisasi dan diperintahkan menyiapkan untuk berperang, pemimpin mereka minum "obat perang", dan pengaruhnya sangat terasa, seperti orang kerasukan (Henk Schulte Nordholt, 2006: 135). Atas jasanya Raden Sastroningrat dikawinkan dengan putri raja Cokorda Pemecutan III yang bernama Anak Agung Ayu Rai sebagaimana sjanjinya. Raden Sastroningrat kemudian memboyong Anak Agung Rai ke Mataram (Yogyakarta), kemudian diajak ke Bangkalan Madura. Setelah masuk Islam Anak Agung Ayu Rai diberi nama Siti Khotijah, dan gelar kebangsawanannya bernama Raden Ayu Mas Mirah (Shaleh Saidi dan Yahya Anshori, 2002: 22).

Sekembalinya dari Jawa, pasangan suami istri segera kembali ke kerajaan Badung dan diterima dengan baik. Namun setelah raja mengetahui bahwa putrinya telah memeluk agama Islam, segera memerintahkan untuk mengasingkan sang putri di Kebon (tempat ini juga disebut Karang Semaya atau Batan Nyuh), yang sekarang ini dikenal dengan Kepaon. Sang putri tinggal di Kepaon beserta para pengikutnya yang sudah beragama Islam dan bermukim turun-temurun sampai sekarang.

Dalam sumber lain diungkapkan bahwa ketika keislaman sudah cukup baik Anak Agung Ayu Rai, oleh suaminya Raden Sastroningrat mengajak untuk kembali ke Bali. Pada suatu waktu yaitu saatnya waktu menunaikan sholat Maghrib, ia dicurigai akan melakukan ngeleak ( santet). Oleh pengawal kerajaan ia dilaporkan kepada sang raja, maka diperintahkanlah untuk membunuhnya. Jadi Anak Agung Ayu Rai dibunuh saat sholat dan mengenakan rukuh (mukena), busana sholat wanita Islam yang berwarna serba putih. Gara-gara memakai pakaian serba putih inilah Anak Agung Ayu Rai dikira akan melakukan prosesi ngeleak. Apalagi saat sholat mengucapkan Allohu Akbar, yang ditelinga orang-orang Hindu Bali dikira 
mengucapkan lakar mekeber (rohnya telah terbang). Oleh karena itu, Anak Agung Ayu Rai secara spontan ditebas kepalanya hingga meninggal (Tim Peneliti Sejarah Masuknya Islam Bali, 1979/1980: 26). Dalam sumber lain dikatakan Anak Agung Ayu Rai dibunuh setelah menunaikan sholat. Ia dipanggil raja untuk menerima hukuman mati karena dituduh mau melakukan prosesi ngeleak. Anak Agung Ayu Rai siap menerima hukuman tersebut. Sebelum menerima hukuman tersebut ia mengatakan bahwa, kalau jasadnya berbau busuk maka ia benar-benar bersalah, sedangkan apabila jasadnya berbau harum maka ia tidak bersalah. Setelah dilakukan eksekusi ternyata jasad Anak Agung Ayu Rai berbau harum. Sang raja mnyesal dan merasa berdosa. Akhirnya Anak Agung Ayu Rai dimakamkan di tempat pemakaman "Setra Ganda Mayu" (kuburan milik kerajaan Badung) ditengah kota Denpasar yang lokasinya berdekatan dengan Puri Raja Pemecutan di Badung (Shaleh Saidi dan Yahya Anshori, 2002: 23). Sampai sekarang makam tersebut lebih dikenal dengan nama "Makam Keramat Puri Pemecutan". Makam tersebut pada bulan suci Ramadhan selalu diziarahi oleh orang Madura dan Jawa yang tinggal di Bali, disamping orang Bali Sendiri. Bahkan sekarang menjadi bagian kunjungan bagi para peserta "wisata ziarah" dari seluruh Indonesia.

Raden Sastroningrat meninggal dan dikuburkan di Ubung. Selama pasangan suami istri Raden Sastroningrat dan Anak Agung Ayu Rai tinggal di Ubung dan Kepaon banyak kerabat Raden Sastroningrat berdatangan atau ikut tinggal di tanah pelungguhan tersebut. Jadi para keturunan pasangan Raden Sastroningrat dan Anak Agung Ayu Rai lengkap dengan para pengikut dan kerabatnya inilah yang menjadi cikal bakal komunitas atau masyarakat Islam di Kampung Kepaon. Namun tidak sedikit juga keturunan mereka yang menyebar ke tempat lain, hal itu disebabkan karena perkawinan maupun pekerjaan, sehingga bersama umat Islam lain yang datang belakangan membentuk komunitas-komunitas baru di berbagai lokasi di daerah Badung. Hubungan masyarakat Islam Kepaon dengan Puri Pemecutan (kerajaan Badung) tetap terjalin dengan baik, bahkan pada setiap upacara kerajaan masyarakat Islam Kepaon mendapatkan undangan dan tempat khusus bagi mereka. Sedangkan pada setiap upacara hari besar Islam di Kepaon selalu dihadiri dari pihak Puri Pemecutan sekalipun agama mereka berbeda yaitu Hindu dan Islam.

Para pengikut pasangan Raden Sastroningrat dan Anak Agung Ayu Rai juga diberikan lahan perkebunan milik kerajaan dan lahan itu sekarang juga telah menjadi bagian kampung Islam Kepaon. Secara etimologis nama Kepaon berasal dari kata ke-paon (bahasa Bali), pawon (bahasa Jawa) yang berarti dapur. Sedangkan secara Toponimi yaitu tentang asal-usul penamaan tempat. Sebagaimana fungsinya toponimi suatu daerah adalah sarana untuk menggali dan mengungkapkan perjalanan sejarah dan budaya suatu wilayah atau kawasan yang dikandung oleh toponimi. Toponimi bisa dijadikan sebagai salah satu sumber sejarah (Anastasia Wiwik Swastiwi, 2010:97). Secara toponimi disebut Kepaon karena masyarakat di kampung Kepaon membangun paon (dapur) di pinggiran desa, sehingga seluruh desa dikelilingi oleh dapur. Setiap orang yang mau ke kampung ini selalu menyebut ke paon, lama kelamaan menjadi Ke-paon sampai sekarang. Secara administratif terletak di Desa Pemogan Kecamatan Denpasar Selatan, Kota Denpasar.

Hingga kini kampung Islam Kepaon terus berkembang baik secara fisik maupun jumlah penduduknya. Meskipun telah mengalami perkembangan yang pesat, namun masyarakat kampung Islam Kepaon tetap menjaga nilai-nilai tradisi dan budaya Bali yang melekat pada diri mereka, karena mereka merasa telah menjadi orang Bali. Masyarakat Islam Kepaon tetap hidup berdampingan dengan orang Bali yang sebagian besar beragama Hindu.

Gambar 1. Masjid Al Muhajrin di Kampung Islam Kepaon aru tahap renovasi

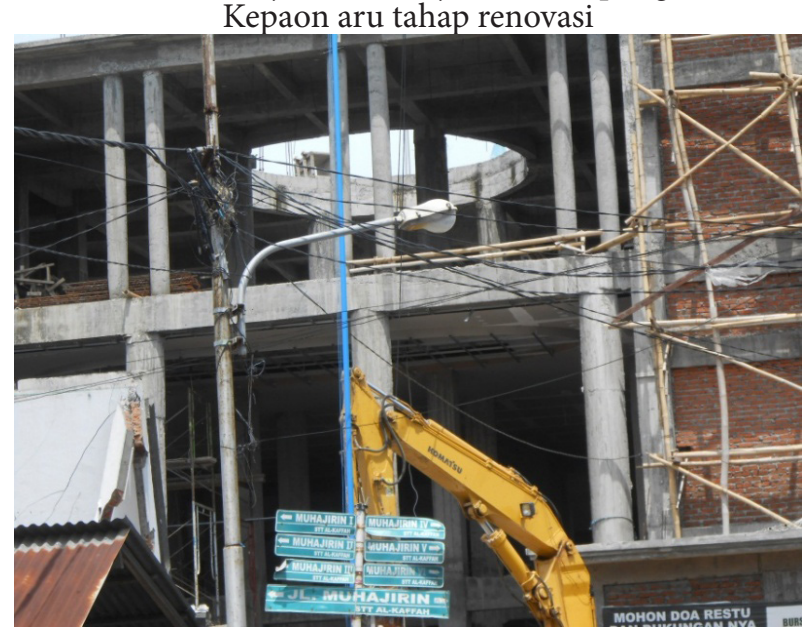

Sumber : Dok. Penulis 2014

\section{Kehidupan Masyarakat Islam Kepaon Akulturasi dan Kehidupan Toleransi}

Akulturasi adalah suatu proses sosial yang timbul manakala suatu kelompok manusia dengan 
kebudayaan tertentu dihadapkan dengan unsur dari suatu kebudayaan asing. Kebudayaan asing itu lambat laun diterima dan diolah ke dalam kebudayaannya sendiri tanpa menyebabkan hilangnya unsur kebudayaan kelompok itu sendiri. Akulturasi menurut Kamus Besar Bahasa Indonesia adalah percampuran dua kebudayaan atau lebih yang saling bertemu dan saling mempengaruhi atau proses masuknya pengaruh kebudayaan asing dalam suatu masyarakat. Dengan demikian masuknya Islam ke Nusantara (Indonesia) dan dalam perkembangan selanjutnya telah terjadi interaksi budaya yang saling mempengaruhi. Namun dalam proses interaksi itu, pada dasarnya kebudayaan setempat yang tradisional masih tetap kuat, sehingga terdapat perpaduan budaya asli (lokal) Indonesia dengan budaya Islam. Perpaduan inilah yang kemudian disebut akulturasi kebudayaan.

Proses akulturasi budaya Hindu dan Islam sebenarnya sudah terjadi sebelum Islam datang ke Bali, bahkan sejak di Persia, India atau di bagian lain kepulauan Nusantara. Keberadaan masyarakat Islam di Kepaon terkait erat dengan kerajaan Badung atau Puri Pemecutan sampai sekarang tetap menjalin hubungan baik. Jika di Puri sedang melaksanakan hajatan atau upacara seperti Pitra Yadnya (upacara kemanusiaan), mesangeh (potong gigi) dan upacara lainnya, tokoh masyarakat Islam Kepaon selalu diundang. Mereka pasti akan datang, bahkan distimewakan kehadirannya dengan posisi duduk dalam setiap hajatan atau upacara adat setingkat dengan para bangsawan Puri (kerajaan Badung). Mereka merasa bahwa eksistensi masyarakat Islam Kepaon secara historis bukanlah pendatang pencari penghidupan melainkan kehadirannya pada waktu itu dibutuhkan oleh kerajaan Badung sebagai kekuatan pertahanan dan keamanan kerajaan. Secara geneologis mereka terdapat pula hubungan darah dengan keluarga raja Badung (Puri Pemecutan). Kesenian asal kampung Islam Kepaon seperti rodat, rebana, hadrah selalu ditampilkan di Puri Pemecutan pada setiap acara atau upacara adat. Ada keselarasan dan keharmonisan ketika rodat musik yang bernuansa Islami tampil bersama gong bleganjur musik tradisional Bali tampil bersama pada acara ritual di Puri Pemecutan Denpasar.

Akulturasi adat kebiasaan memang telah lama terjadi di kampung Islam Kepaon. Mereka mempunyai hubungan yang erat dengan Puri Pemecutan yang Hindu, komunitas Islami di Kepaon. Dalam upacara kematian misalnya, para pelayat yang mengantarkan ke kuburan membaur antara yang berpakaian adat Bali dan yang berpakaian busana muslim mengenakan songkok (kopiah). Selama akulturasi sifatnya artifisial semacam itu oleh para leluhur yang memiliki kearifan lokal dianggap tidak bermasalah. Identitas masyarakat Islam kampung Kepaon penuh akulturasi, dalam jalur geneologis dan kultural, hal ini menjadi akar keharmonisan dalam hubungan komunitas Hindu disekelilingnya.

Hubungan baik antar komunitas serta toleransi kehidupan di kampung Islam memang terjalin dengan baik. Banyak adat serta tradisi yang bisa dijadikan titik tolak untuk membangun semangat toleransi dan persaudaraan. Toleransi menurut Kamus Umum Bahasa Indonesia, Toleransi yang berasal dari kata "toleran" itu sendiri berarti bersifat atau bersikap menenggang (menghargai, membiarkan, membolehkan), pendirian (pendapat, pandangan, kepercayaan, kebiasaan, dan sebagainya) yang berbeda dan atau yang bertentangan dengan pendiriannya.Toleransi juga berarti batas ukur untuk penambahan atau pengurangan yang masih diperbolehkan. Toleransi dalam beragama bukan berarti kita harus hidup dalam ajaran agama lain.Namun toleransi dalam beragama yang dimaksudkan disini adalah menghormati agama lain. Dalam bertoleransi janganlah kita berlebih-lebihan sehingga sikap dan tingkah laku kita mengganggu hak-hak dan kepentingan orang lain. Lebih baik toleransi itu kita terapkan dengan sewajarnya. Jangan sampai toleransi itu menyinggung perasaan orang lain. Toleransi juga hendaknya jangan sampai merugikan kita, contohnya ibadah dan pekerjaan kita.

Salah satu wujud dari toleransi hidup beragama adalah menjalin dan memperkokoh tali silaturahmi antarumat beragama dan menjaga hubungan yang baik dengan manusia lainnya. Merajut hubungan damai antar penganut agama hanya bisa dimungkinkan jika masing-masing pihak menghargai pihak lain. Mengembangkan sikap toleransi beragama, bahwa setiap penganut agama boleh menjalankan ajaran dan ritual agamanya dengan bebas dan tanpa tekanan.Oleh karena itu, hendaknya toleransi beragama kita jadikan kekuatan untuk memperkokoh silaturahmi dan menerima adanya perbedaan. Dengan ini, akan terwujud perdamaian, ketentraman, dan kesejahteraan. Tradisi "ngejot" (memberi hidangan/ mengantar makanan ke tetangga non muslim) sejak dahulu sampai sekarang telah menjadi tonggak dalam menciptakan toleransi, kemesraan dan 
persaudaraan Hindu dan Muslim di Bali termasuk di kampung Kepaon.

Umat Islam "ngejot" dengan mengirim makanan menjelang hari raya Iedul Fitri ke tetangatetangganya yang beragama Hindu. Sebaliknya umat Hindu juga melakukan hal yang sama menjelang hari raya Nyepi, Galungan, dan Kuningan. Untuk mencegah munculnya keraguan tentang kehalalan, makanan yang dikirimkan umat Hindu biasanya tidak berupa masakan melainkan buah-buahan. Tradisi ini mencerminkan keakraban dalam kehidupan yang secara tidak langsung memberi dampak positif dalam membangun kerukunan hidup antar umat beragama yang hidup bertetangga. Konsep "menyama braya" yakni persaudaraan yang betul-betul diterapkan dalam kehidupan umat beragama di Bali diterapkan. Istilah Nyama Selam digunakan masyarakat Bali yang beragama Hindu untuk menyebut orang Pegayaman dan Nyama Bali adalah sebutan yang dipakai penduduk beragama Islam bagi masyarakat Bali yang beragama Hindu. Nyama adalah kata dalam bahasa Bali yang artinya saudara sedangkan Selam adalah pengucapan kata Islam oleh orang Bali tempo doeloe. Sama sekali tidak ada konotasi negatif, apalagi penghinaaan. Justru dengan istilah ini mempertegas kerukunan karena dikaitkan dengan ikatan persaudaraan yang di Bali dikenal istilah menyama-braya. Dalam istilah menyama braya ini umat Hindu melahirkan istilah nyama selam (saudara Islam) dan nyama Kristen (saudara Kristen).

Tradisi "megibung" (makan bersama) meskipun itu berasal dari tradisi Hindu, karena tidak bertentangan dengan nilai-nilai Islam tetap dilaksanakan di kampong Islam Kepaon. Meskipun dilaksanakan ketika selesai membaca Alquran, atau khataman. Megibung merupakan tradisi Bali yang mengandung makna kebersamaan. Makan bersama dengan beberapa orang dengan satu nampan yang sama diharapkan dapat meningkatkan tali persaudaraan antar umat. Makanan yang tersaji sangat bervariasi, namun semua masih cita rasa masakan khas Bali, berupa base genep (bumbu genap). Seperti masakan ayam base genap, plecing, sambal matah, dan lainnya. Minumannya juga beragam seperti es kolak, es blewah, brongko (minuman khas buka puasa di Kepaon yang terbuat dari tepung kanji, gula, dan santan).
Gambar 2. Madrasah Aliyah Yayasan AlMuhajirin Kampung Islam Kepaon

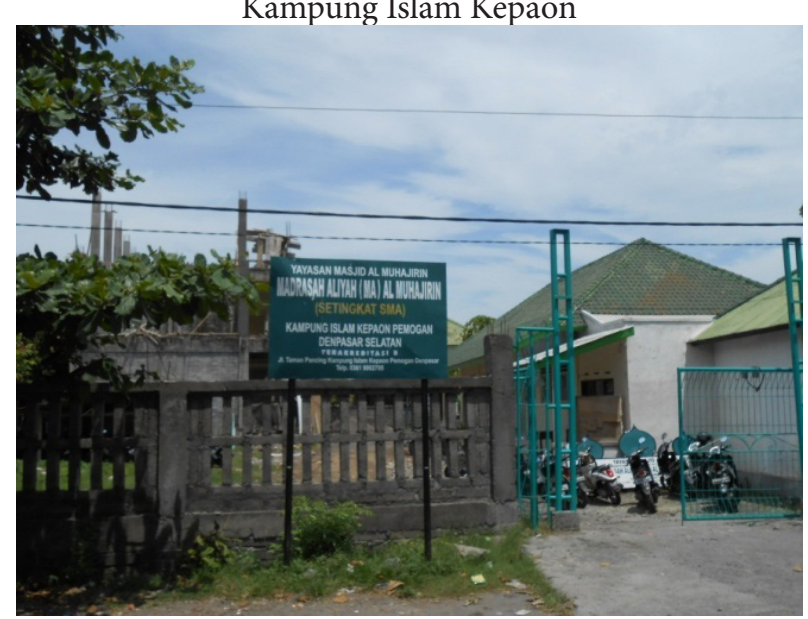

Sumber: Dok Penulis 2014

\section{Bahasa dan Pendidikan}

Interaksi masyarakat kampung Islam Kepaon menggunakan bahasa Bali dalam kesehariannya. Berbeda dengan masyarakat Islam kampung Loloan Kabupaten Jembrana, mereka menggunakan bahasa Melayu yang dipengaruhi oleh bahasa Jawa, Bali, dan Bugis yang memunculkan dialek Loloan (Armini, 2009: 15). Nama-nama masyarakat Bali seperti Putu, Made, Kadek, dan Ketut juga dipakai masyarakat Kepaon sebagai julukan. Bedanya, nama-nama khas Bali yang menunjukkan urutan kelahiran dalam keluarga itu tidak diformalkan secara administratif, melainkan hanya sebuah panggilan sehari-hari. Yang diformalkan adalah masyarakat Islam yang ada di kampung Pegayaman Kabupaten Buleleng.

Mendengar nama Putu, Made, Nyoman dan Ketut pastilah orang menebak bahwa pemilik nama tersebut adalah orang Bali. Hal itu memang tidak salah karena nama-nama tersebut adalah nama bagi orang Bali. Dengan menambah huru "I" di depan nama itu menunjukkan pemiliknya adalah laki-laki, sedang untuk perempuan mendapat tambahan kata "Ni". Bagaimana dengan nama Ni Made Fatima, karena Fatima identik dengan nama seorang Muslimah (orang Islam perempuan). Sedangkan nama Ni Made adalah nama orang Bali yang identik dengan Hindu sebagai agama sebagian besar orang Bali. Itulah perpaduan nama yang menarik yang ada di Desa Pegayaman. Ni Made Fatima adalah seorang muslimah dari Bali, yaitu di Desa Pegayaman. Bersama nama-nama lain seperti Ketut Asghor Ali, Nengah Panji Islam, Wayan Imam Muhajir, dan lain-lain mereka menjadi penduduk asli Pegayaman, yang secara turun-temurun sejak abad XVI tinggal di desa tersebut (Nuryahman, 2013: 300). 
Para tokoh masyarakat di kampung Islam Kepaon menyadari bahwa pendidikan sebagai usaha membentuk pribadi manusia harus melalui proses yang panjang, dengan resultat (hasil) yang tidak dapat diketahui dengan segera. Berbeda dengan membuat atau membentuk benda mati yang dapat dilakukan sesuai dengan keinginan pembuatnya. Dalam proses pembentukan tersebut diperlukan suatu perhitungan yang matang dan hati-hati berdasarkan pandangan dan pikiranpikiran atau teori yang tepat, sehingga kegagalan atau kesalahan-kesalahan langkah pembentukan terhadap anak didik dapat dihindarkan. Oleh karena lapangan tugas dan sasaran pendidikan adalah makhluk yang sedang hidup tumbuh berkembang dan berkembang yang mengandung berbagai kemungkinan. Bila salah bentuk maka akan sulit untuk memperbaikinya kelak.

Pendidikan Islam bila dilihat dari segi kehidupan kultural umat manusia tidak lain adalah merupakan salah satu alat pembudayaan (enkulturasi) masyarakat manusia itu sendiri. Sebagai suatu alat, pendidikan dapat difungsikan untuk mengarahkan pertumbuhan dan perkembangan hidup manusia, (sebagai makhluk pribadi dan makhluk sosial) kepada titik optimal kemampuan untuk memperoleh kesejahteraan hidup di dunia dan kebahagiaan hidup di akhirat. Dalam hal ini, maka kedayagunaan pendidikan sebagai alat pembudayaan sangat bergantung kepada pemegang alat tersebut yaitu para pendidik. Dengan demikian maka para pendidik memegang posisi kunci yang banyak menentukan keberhasilan proses pendidikan, sehingga mereka dituntut persyaratan tertentu, baik teoritis maupun praktis, dalam pelaksanaan tugasnya. Sedangkan faktor-faktor yang bersifat internal seperti bakat atau pembawaan anak didik dan faktor eksternal seperti lingkungan dalam segala dimensinya menjadi sasaran pokok dari proses ikhtiariah para pendidik (Nur Ubiyati, 1997: 11).

Mengingat arti pentingnya dan tujuan sebuah pendidikan tersebut, maka di kampung Islam Kepaon juga dilaksanakan pendidikan dari tingkat dasar hingga menengah. Pelaksanaan pendidikan di kampong Islam Kepaon ada yang didirikan oleh pemerintah melalui Kementerian Agama yaitu Madrasah Ibtidaiyah Negeri (MIN), sedangkan yang dikelola swasta yaitu yang diselenggarakan oleh Yayasan Al-Muhajirin di Kepaon. Yayasan tersebut membina sekolah sejak dari TK (Roudhatul Atfal), Madrasah Ibtidaiyah (MI), Madrasah Tsanawiyah (Mts), dan Madrasah Aliyah (MA).Di Kampung
Islam Kepaon tidak ada Pondok Pesantren seperti yang ada di kampong Islam Pegayaman.Disamping di Masjid Al Muhajirin juga dilaksanakan Taman Pendidikan Al Quran (TPQ).

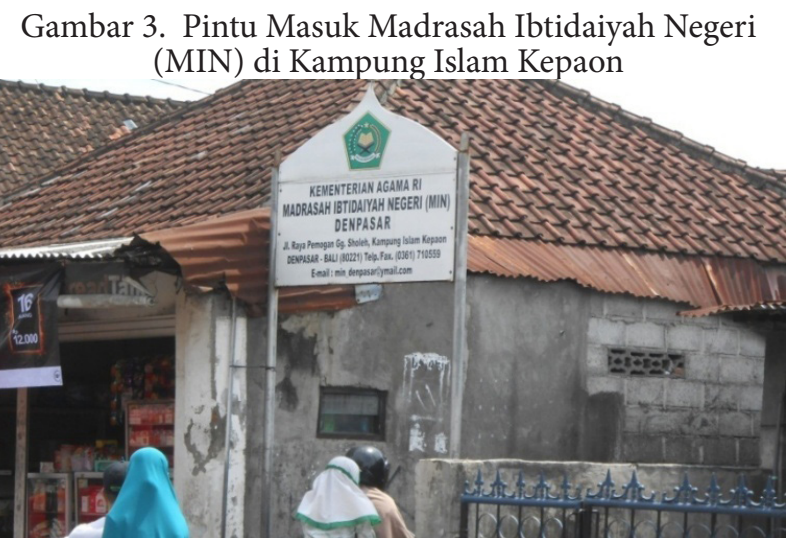

Sumber : Dok. Penulis 2014

\section{PENUTUP}

Kampung Islam Kepaon adalah salah satu perkampungan Islam yang ada di Bali dan sudahada sejak jaman kerajaan di Bali. Keberadaan masyarakatnya mempunyai hubungan baik geneologis maupun kultural dengan kerajaan Badung yaitu Puri Pemecutan. Kehidupan masyarakat Islam di kampung Kepaon yang ada di wilayah desa Pemogan kecamatan Denpasar Selatan Kota Denapasar mencermnkan suasana yang harmonis dan sesuai semboyan bangsa Indonesia "Bhineka Tunggal Ika. Akulturasi budaya Islam dn Hindu Bali terjadi disana, kehidupan yang penuh toleransi telah menghasilkan suasana keharmonisan dan kedamaian.

Dalam kehidupan sehari-hari mereka menjalin hubungan yang penuh kekeluargaan walaupun berbeda keyakinan. Setiap ada acara baik itu bersifat suka maupun duka mereka saling menghadiri dan memberikan sesuatu baik materi, ipasdoa, dan tenaga partisipasi yang nyata.Suasana seperti itu yang dibutuhkan oleh bangsa Indonesia dalam membangun kebersamaan, sehingga persatuan dan kesatuan bias diwujudkan. Dalam menghadapi era yang global dan serba modern kehidupan kebersamaan, harmoni dan perdamaian sangat diperlukan. Dalam hal pendidikan suasana di kampong Islam Kepaon kiranya bias dijadikan laboratorium hidup bagi generasi untuk belajar hidup bersama yang penuh toleransi.

\section{UCAPAN TERIMA KASIH}

Terima kasih kepada para dosen Jurusan Sejarah Fakultas Sastra Universitas Udayana 
yang telah memberi dorongan dan penambahan pemahaman teori untuk kajian ini. Juga kepada Kepala Balai Pelestarian Budaya Bali, NTB,NTT yang memberikan ijin dan waktu untuk kajian ini. Para petugas perpustakaan baik perpustakaan Daerah, Fakultas Sstra, Universitas, yang telah banyak membantu pada waktu studi pustaka. Semua pihak terutama masyarakat kampung Islam Kepaon, teman-teman peneliti BPNB yang telah berperan besar terselesainya penulisan ini. Semoga semuanya menjadi amal baik, mudah-mudahan juga tulisan ini bisa berguna dan membawa manfaat.

\section{DAFTAR PUSTAKA}

Ardika, I Wayan.2007. Pusaka Budaya dan Pariwisata.Denpasar : Pustaka Larasan

Armini, I Gusti, 2009. "Akulturasi Budaya Masyarakat Loloan". Dalam Jurnal Penelitian Sejarah dan Nilai Tradisional, Edisi 31, No. 31/X/2009, Denpasar, Juni 2009.

Gottschalk, Louis. 1986. Mengerti Sejarah. Ter. Nugroho Notosusanto. Jakarta : Universitas Indonesia Press.

Koentjaraningrat, ed. 1997.Metode-Metode Penelitian Masyarakat. Jakarta : Gramedia Pustaka Utama - edisi ketiga.

Nuryahman, 2013. " Perkembangan Pendidikan Islam di Desa Pegayaman, Kecamatan Sukasada, Kabupaten Buleleng”. Dalam Jurnal
Penelitian Sejarah dan Nilai Tradisional, Vol.20, No.2, Denpasar, September 2013.

Pitana, I Gde, 2002. Pariwista, Wahana Pelestarian Kebudayaan dan DinamikaMasyarakat Bali. Denpasar : Universitas Udayana.

Poerwodarminto, WJS., 1976. Kamus Umum Bahasa Indonesia. Jakarta : Balai Pustaka.

Saidi, Shaleh dan Yahya Anshori, 2002. Sejarah Keberadaan Umat Islam di Bali. Denpasar : Majelis Ulama Indonesia (MUI) Bali.

Saidi, Shaleh. 2007. Lingua Franca Menelisik Bahasa dan Sastra Melayu diNusantara, dari Riau hingga Bali. Denpasar : Pustaka Larasan.

Schulte Nordholt, Henk. 2006. The Spell of Power, Sejarah Politik diBali 1650 -1940. Denpasar : Pustaka Larasan kerjasama dengan KITLVJakarta

Schulte Nordholt, Henk. 2010. Bali Benteng Terbuka 1995 -2005, Otonomi daerah, demokrasi electoral, dan identitas-identitas defensive. Denpasar : Pustaka Larasan kerjasama dengan KITLV-Jakarta.

Tim Peneliti Sejarah Masuknya Islam Bali, 1979/1980. Sejarah Masuknya Islam diBali. Denpasar : Proyek Penelitian Pemda Tingkat I Propinsi Bali.

Ubbiyati, Nur, 1997. Ilmu Pendidikan Islam (IPI). Bandung: Pustaka Setia

Wiwik Swastiwi, Anastasia, 2010. Toponimi Daerah Natuna. Tanjung Pinang : Balai Pelestarian Sejarah dan Nilai Tradisional Tanjung Pinang. 